\title{
BLENDING OR ADJUSTING MODESTY IN STYLING FASHIONABLE HIJAB? A STUDY AMONG MALAY WOMEN ACADEMICIANS AT A PRIVATE UNIVERSITY IN PERAK
}

\author{
Bazlin Darina Ahmad Tajudin ${ }^{1}$ \\ Lecturer in Department of Public Relations, \\ Faculty of Arts and Social Science, \\ Universiti Tunku Abdul Rahman (UTAR), Malaysia \\ (Email: bazlin@utar.edu.my) \\ Darren Yoong Wei Tung ${ }^{2}$ \\ Student of Universiti Tunku Abdul Rahman (UTAR), Malaysia \\ (Email: darrenyoong@gmail.com) \\ Goh Chun Ghee ${ }^{3}$ \\ Student of Universiti Tunku Abdul Rahman (UTAR), Malaysia \\ (Email: chunghee0615@gmail.com) \\ Lee Jia $\mathrm{An}^{4}$ \\ Student of Universiti Tunku Abdul Rahman (UTAR), Malaysia \\ (Email: jiaan93@gmail.com) \\ Lee Pui Yee ${ }^{5}$ \\ Student of Universiti Tunku Abdul Rahman (UTAR), Malaysia \\ (Email: puiyeelee08@gmail.com) \\ Lee Zheng $\mathrm{Da}^{6}$ \\ Student of Universiti Tunku Abdul Rahman (UTAR), Malaysia \\ (Email: dalee96@gmail.com) \\ Teh Su Yen ${ }^{7}$ \\ Lecturer in Department of Public Relations, \\ Faculty of Arts and Social Science, \\ Universiti Tunku Abdul Rahman (UTAR), Malaysia \\ (Email: tehsy@utar.edu.my)
}

Accepted date: 05-03-2019

Published date: 08-07-2019

To cite this document: Bazlin, D. A. T., Darren, Y. W. T., Goh, C. G., Lee, J. A., Lee, P. Y., Lee, Z. D., \& Teh, S. Y. (2019). Blending or Adjusting Modesty in Styling Fashionable Hijab? A Study Among Malay Women Academicians at A Private University in Perak. International Journal of Modern Trends in Social Sciences, 2(8), 55-63.

DOI: $10.35631 /$ IJMTSS.28006

Abstract: Hijab has always been related to religious terms. It is donned in order to observe the aurah of a Muslim woman. However, as the fashion industry continue to blossom, fashion has been applied into styling of hijab. As a result, what is supposed to be modest has been turned into a fashion statement instead. With this, the rise of fashion hijab raised an alarming issue that the fashionable hijab styling contradicts with the Islamic rule of modesty. Therefore, this 
paper $^{l}$ aims to find out the way modesty entails in styling fashionable hijab among Malay women academicians in a private university located in Perak. The research employed in-depth interview of four female Muslim lecturer with age range of 35 to 40 years old. The criteria of selecting the interviewees are Muslim women, hijab wearer, wearing hijab style of the current trend and having purchasing power to buy the latest hijab brands. In this research, it is found that modesty can be affected by fashion when a hijab is donned. The hijab wearers understood the Islamic guidelines of modest clothing but tend to integrate the concepts in betting the fashionable component. However, hijab wearers that are motivated by fashion adjusted the modesty component in their style. The adjustment of modesty was conform by society via media and celebrity portrayal of fashionably modest hijab. As a result, fashion has been pushed into being seen as modest, and modest means fashion.

Keywords: Hijab, Acceptance, Fashionable, Academician, Perak

\section{Introduction}

The issue of modesty in Islamic clothing that connected with the concept of awra'. modesty in Islamic clothing is viewed physically which is connected with the concept of awra', an Arabic term meaning 'inviolate vulnerability' or 'what must be covered' and consisting of the private body parts of a human being (El Guindi 1999, p. 142). Women's concept of awra' is more extensive compared to men. A woman's awra' that consists of her entire body such as the back, abdomen, thighs and two private parts, with the exception of her face and hands cannot be disclosed to men outside her mahrem, i.e., family members and those forever ineligible for marriage to her as well as non-Muslim women (Al-Qaradawi 1995, p. 160). Three Quranic references that discuss the ruling of hijab which is compulsory to all Muslim female and the appropriate hijab styling. Women clothing in Islam focuses on modesty of three items namely, headscarves, garment and finery. Firstly, in Surah An-Nur (24) ayah 31, the Quran uses the Arabic word khimar to refer to women's headscarves says that "And tell the believing women to reduce [some] of their vision and guard their private parts and not expose their adornment except that which [necessarily] appears thereof and to wrap [a portion of] their headcovers over their chests and not expose their adornment except to their husbands, their fathers, their husbands' fathers, their sons, their husbands' sons, their brothers, their brothers' sons, their sisters' sons, their women, that which their right hands possess, or those male attendants having no physical desire, or children who are not yet aware of the private aspects of women. And let them not stamp their feet to make known what they conceal of their adornment. And turn to Allah in repentance, all of you, O believers that you might succeed." Secondly, the outer garment or in Arabic known as jilbab must be must be loose-fitting and non-transparent clothing that covers the whole body, maybe with the exception of the hands and face as mention in Surah Al-Ahzab (33) ayah 59, "O Prophet, tell your wives and your daughters and the women of the believers to bring down over themselves [part] of their outer garments. That is more suitable that they will be known and not be abused. And ever is Allah Forgiving and Merciful." Thirdly, women are not to vaunt their accessory as stated in the Quran using the Arabic word zinah to refer to their "finery," Surah Al-Ahzab (33) Ayah 33 says that "stay at home, and do not flaunt your finery as they used to in the pagan past; keep up the prayer, give the prescribed alms, and obey God and His Messenger. God wishes to keep uncleanness away from you, people of the [Prophet's] House, and to purify you thoroughly."

\footnotetext{
${ }^{1}$ This paper is to fulfill a publication requirement under UTAR Research Fund (UTARRF).
} 
Islamic veil, or more commonly known as hijab is worn by Muslim women to impose Islamic values that are based on the teachings of the Qur'an that aims to protect women and their dignity (Hassim, 2014). Religion is belief whereas religiosity is more about the valuation of the quality and state of mind of an individual which is based on religious values that turn into their conviction. A person's religiosity more or less will have an impact on the one's behaviour (Agorastos, Demiralay \& Huber, 2014). As mentioned in the holy Qur'an, religiosity means modest dressing and covering the aurah (Syahrul, 2017). Therefore, wearing hijab is a sign of fidelity to their religiosity and a recognition of the act as God's commandment (Majid, 2016).

The recent spotlight in Muslim fashion has transformed Hijab as a fashion statement which was never meant to be. It somehow diverts the true meaning of wearing hijab. Fashion is an expression of oneself and with the hype hijab more Muslim women tend to experiment blending modesty and personal style into their appearances. Despite the obvious contradiction with the spirit of hijab, a growing number of Muslim women are blending the two. The practice of headscarf is an essence of Islamic value. It is an act of obedience that has been clearly defined in the Qur'an and Sunnah. This recent interest in Muslim fashion also signals the changing dynamics of traditional and modern culture of the Islamic hijab. Modification in Hijab fashion can be accepted in this era as one of fashion styles. Although the stylish hijab cover everything but it does not meet the overall requirement of the hijab. There are guidelines for women to follow in wearing hijab which is covering the chest with apparent that is loose and covering your body and nor revealing the shape of your body. In addition, fashionable attire and accessory that can attract the attention of men should be avoided as it is also against the basic idea of modest clothing in Islam. With this, the significant and actual perspective of Hijab should be reinforced so that no mislead of Islamic values (Boulanouar, 2006, p. 140; Woldesemait, 2012, p. 19; Zulkifli and Fatin, 2013, p. 50; Rizvi, 2014 \& Rita, 2017, p. 342).

\section{Problem Statement}

Hijab in the media today is being portrayed rather fashionably than modestly. Fashion designers have the power to shape society's acceptance toward hijab in terms of Islamic concept of modesty or following the latest style in the fashion industry. For instance, Neelofa's stylist, Diyana Zainul Ehsan mentioned that, "the hijab does not restrict you from being fashionable, with the right and befitting outfit, you can boldly present yourself to the world" (Mustapha, 2017). Melanie Elturk, CEO of Haute Hijab also commented that, "modesty means a lot more than just covering the aurah, it means a sense of shame. The way we converse and act, speak with humility about matters that are private, the way we show ourselves to the public.

Modesty comes from within, not the outfit you are in" (Elturk, 2012). With this, Malaysian women are been affected by the controversy of hijab wearing and tend to look towards beauty as well as fashion of hijab that influences their hijab styling (Hassim, 2014). In addition, this may create a conflicted mindset upon the Muslim either to uphold a tradition or follow the current society into the ever-changing trend of modernism (Hamzah, Ismail, Mustari \& Basiron, 2014). Hence, this research is trying to find out the acceptance of fashionable hijab trends among Malay women academicians in a private university located in Perak. The acceptance of fashionable hijab will be explored in terms of understanding the concept of modesty and the meaning of fashionable hijab wore by women academicians.

\section{Research Objective}

To find out the way modesty entails in styling fashionable hijab among Malay women academicians in a private university located in Perak 


\section{Literature Review}

Hassan, Anas and Santosa (2015) study, Muslim women understood the concept of dressing modestly. It is found that people will likely to follow all the principle of Islam even if fashion keeps on changing. This shows that they have knowledge in choosing the suitable Muslim clothing. However, Prihandini and Suminar (2017), study found that despite knowing that fashionable hijab does not ideally compliance with Islamic principles, but the respondent felt more confident and complacent in wearing it compared to the traditional hijab. In addition, respondents felt that by wearing fashionable hijabs, it would serve as an encouragement to the non-wearers to start donning a hijab due to it not being old and traditional.

Hasna and Hati (2017), research found that factors that influence donning fashionable hijab are dressing style as well as knowledge about fashion industry. Furthermore, income too factored in one's decision to wear fashionable hijab. Furthermore, Zulkifli and Fatin (2013), research shows that women are also influenced by media in wearing hijab. The respondents agreed that fashionable hijab is a symbol of new creation of the fashion designer than as a pride of Muslim women towards value of hijab wearing. Hence, the trend created confused the purpose of Hijab wearing in Islam. Deniz (2014) research found that Muslim women are grown to the fashion industry and veiling is a symbol of religion that portrayed them differently from others. The rising of fashionable hijab somehow effects the Muslim women in terms of socioeconomic status. The fashionable hijab was condemned by some respondents because it labels them to certain economic status. It is because the branded hijab is mainly attracting women from higher income and those with luxurious lifestyle.

According to Maqsood, Cluver, and Chen (2016) research found that women felt the traditional hijab is uncomfortable and not convenient as it to be adjusted frequently or needed to be pinned in order to keep the hijab in place. Respondents stated that solution required in order to ensure the hijab stabilised on their heads and have a one-piece fabric that allows them to cover both hands and face simultaneously. The materials of traditional hijab are of concern it did not provide the better breathable functions. Modifying hijab in terms of style and material allows women to don hijab appealingly and comfortably. In addition, the new style able to make them more accepted by the non-Muslim. Whereas, Afroza (2017), found that wearing of

hijab is considered as being fashionable. The respondents thought that the changing of hijab style could be part of fashion. It is found that, the rising of new hijab trend motivates Muslim women to wear hijab today. It is because they want to embrace the new fashion trend, simultaneously fulfilling their religion obligation.

\section{Methodology}

The research employed in-depth interview of four female Muslim lecturer with age range of 35 to 40 years old. The criteria of selecting the interviewees are Muslim women, hijab wearer, wearing hijab style of the current trend and having purchasing power to buy the latest hijab brands. The interview questions focuses on two main aspects namely, the concept of modesty and acceptance of hijab styling from uprising fashionable hijab brands. Latent coding was used in analysing the interviewee's text. The themes were derived based on the underlying and implicit meanings of hijab, modesty and fashion from the text. Factual information about hijab depended on the context described by the respondents. The research able to come up with two main themes namely (1) understanding the concept of modesty in compliance with Islamic guideline and (2) styling of hijab focusing on blending or adjusting the concept of modesty in befitting the trendy fashion. 


\section{Findings and Discussion}

The first finding is understanding the concept of modesty in compliance with Islamic guideline. Modesty in Islam is view in the Islamic guideline on the concept of aurah. The research found that all respondents understood the basis of Islamic guideline of donning hijab modestly. A statement from respondent A stated as follow:

"The ultimate purpose of donning hijab is to cover our aurah as a woman such as covering our hair and body is because of religious teachings. Consequently, modesty is a guideline stated in the Quran, for instance, if you want to wear a hijab you have to wear it properly, which means that you must lower your hijab until it covers a certain part of your body, so for me this is modesty."

It is found that the focus of modesty in donning hijab is described as covering of certain women's body parts and hijab's material. A part from that, the intention of wearing hijab can determined the modesty component is observed by the wearer. Respondent B described an acceptable hijab as:

"The hijab material must not be too thin in order to cover one's aurah. The most important is to explore the purpose of wearing hijab, because people nowadays only follow half of the requirement of wearing hijab such as having the material to be too sheer or over accessories their hijab appearance with seen jewellery. It is because Hijabi today focus so much on fashion than religious purpose of hijab."

Apart from being a religious component, modesty can be discussed in terms of cultural acceptance. It is because hijab styles vary across cultural continents which makes modesty in hijab perceive differently from different countries. In addition, modesty can be flexibly interpreted by the wearers as long as they are clear on their attention by putting on a hijab. The statement from respondent $\mathrm{C}$ describing fashionable hijab as follows:

"The purpose of being modest in clothing is the need to cover yourself. You need to choose a suitable hijab for your comfort and unique style. Hijab styles are different based on cultural preferences such as Asian and Westerner. Hijab can be modest and fashionable as long as you follow the rules Islam. So, in actuality, you can still be fashionable simultaneously adhering to religion guideline.'

An acceptable hijab can be interpreted by the individual intention of donning hijab. Furthermore, Hijabi is adapting to the up to date trend of fashion at the same time keeping the modest components in styling their veil.

The second finding focuses on hijab styling and the integration of modesty. Islamic guidelines in donning hijab focuses of three components namely, (1) headcovers that is covering of chest; (2) apparel that are loose-fitting and non-transparent which covers the whole body except for the hand and face; and (3) not exposing their accessory to be adorned by others It is found out that modesty can be seen in the hijab styling in terms of blending or adjusting. Firstly, blending modesty with fashionable hijab means following the three-set guideline of clothing in Islam. It is found that, respondents opt on the material and affordability in purchasing certain hijab rather than following the brand hijab's style. It is because hijab is don for the convenience of time and comfort. A statement from respondent B as follows: 
"I changed my hijab styling because of the hijab material and fashion. In the past, instant hijab was famous, then the bawal hijab becomes a hit and now the shawl or a long scarf is the "it" trend. I just follow the latest trend, like what they sell, as long as the hijab can cover my aurat. I would not buy the material nor follow the style, even though the design is very good because the material is too thin that depict the purpose of donning hijab."

Although the rising of hijab brands with their signature styling, the study found that wearers reject certain style that they do not deem as appropriate. For instance, all the respondents rejected the turban style and sheer cloth hijab because it could misconstrue the purpose of hijab along with concepts of modesty. A statement from respondent A strengthen the above claim:

"Sometimes I get influenced by Hijabi trendsetter, but when you talk about modesty, it does not matter how nice their style is if it is against the Islamic principle or my principle of modesty, then I will not follow. However, some people do, for instance, if you see they wear hijab properly, it is because of religious and modesty purposes. But, style like the turban hijab are accepted by some and they thought the covering of the hair alone is good enough to be considered as donning hijab. Then again, Islamic guidelines on the modest veiling emphasis that if you want to wear a hijab you have to wear it properly, you cannot just wear it to cover the hair yet still showing part of your neck and/or ear by right those parts needs to be properly covered."

Today, hijab has become more that the symbol of religious commitment, but also a woman's statement of individuality. Styling fashionable hijab enable wearers to experiment with their looks and able to feel a sense of self-satisfaction for their appearance. Therefore, it is important to blend the concept of modesty in fashioning one's hijab in order to observe the aurah and be fashionable at the same time.

Secondly, adjustment can be made to the component of modesty so that one can be perceived as fashionable in donning hijab. The adjustment of modest hijab mainly been made in terms of length and accessory. Firstly, the lowering of hijab to the length of covering one's chest is adjustable based on the occasion and jewellery that one's accessories with their hijab. The respondents defined accessory into functionality and attractiveness. The functionality of accessory donned with hijab such as pins and brooches is to keep the hijab in place. As for attractiveness, accessories like necklaces and dangling earrings are an option for them to be fashionable in donning their hijab as they dress up for special or fancy occasions. Two of the respondents viewed wearing accessory with their hijab is for the purpose of functionality rather than attractiveness. They stated women these days had the wrong perception toward lavishing accessories on their hijab. This claim can be corroborated from respondent D as follow:

"Nowadays, wearing big dangling earrings to the point that she has to show a part of her ear that supposed to be covered when you don hijab is not proper. The style is very popular among Hijabi these days. I perceived this style is not according to Islamic guideline, because a woman's aurah comprises using of accessory that are not meant to attract others gaze. However, small accessory such as pins and brooches that been use to make your hijab to be in place is acceptable because those accessories necessitates hijab wearing." 
Whereas, the other two respondents claimed that they can still accessories with necklaces and earrings in order to look attractive if their aurah are covered. However, at times fashion taken higher tolls than being modest. Respondent $\mathrm{C}$ evidently said that:

"Actually, it depends on the occasion that you are attending. If you are going to an annual dinner, then you will wear some jewellery for you to look better. Normally, when you put accessory like the necklace to style your look, you must don your hijab bit shorter that at times you will not be able to cover the chest area fully. This is more about being fashionable than the right way to don hijab in Islam, because Islam requires you to cover the bosom."

The components of modesty is been adjusted due to the influence of media and celebrity portrayal of fashionable hijab. The study found the meaning of the fashionable hijab shift from mixing fashion and religion compliance into solely focusing on being trendy. Respondent $\mathrm{A}$ described fashionable hijab as follows:

"Some fashion hijab meets the religion requirement, while some does not. Nowadays, some hijab able to mix fashion and religion requirement, and some only want to be fashionable. Actually, the style of hijab can determine if the person wear it for the sake of religion or fashion wise."

Now, emerging style of hijab is considered as modest due to popularity of Hijabis' trendsetter and hijab brand influencers that has been mushrooming in Malaysia market resulting social acceptance of fashionable hijab. Furthermore, Instagram, Facebook and YouTube are platform to disseminate the influence of trendy hijab. Respondent A again stated that:

"Hijab is becoming a trend these days among Muslimah. Back then, around 20 years ago when I was younger, even on media such as news, it is very rare to see hijab don by TV announcer or anchor. These days, media industry had made changes where you can see hijab portray in many instances, such in TV programmes, advertisements, celebrities etc. and all shows hijab based on different approaches. Even social media platforms are trending with hijab portrayal. I learned most of the styling of hijab from video I watch on Facebook, YouTube and now extensively gets tutored on the latest hijab style via Instagram. One thing that is good about it, is that, media teach people about modesty, especially among Muslim women, whereby the awareness is increasing about Islamic teaching where you have to cover up yourself, but I think it is also a problem where people only wear it for the sake of fashion."

Donning a fashionable hijab allows women to be presentable and set an example to young hijab wearers. It is found that academician opt for fashionable hijab style in order to look presentable as a woman. Fashionable hijab styling is emerging rampantly and has influenced women of all ages in their appearance. Trendy style allows young girls starts to donned hijab as part of their religious obligation simultaneously introducing a pleasurable ambience for them to experiment with various types of hijab styling. However, the Hijabi trendsetter that adjusted the hijab appearance by opting for fashion rather than modesty could ruin the concepts of aurah. Respondent D stated that: 
"The new styles of hijab are elegant and sophisticated that allows me to be confident in my appearance as an academician, therefore I want to be a role model and show some good example so that maybe when teenagers look at me, they can don hijab and still do fashion at the same time but in a proper way and presentable. But nowadays, teenagers, adult or career women, tend to follow the latest trend of hijab. Initially, I do follow the trendy hijab style but I realised later that it is not necessary because I can wear as I deem fit and still look updated. It is because some of the fashionable hijab did not place covering of aurah as priority, for example, the scarf is too short or the style did not properly covering the chest area, the turban concepts that mainly cover the head but left the neck area to be exposed or wearing the tide clothing."

Based on the findings of this research it can be said that modesty can be affected by fashion when hijab is don. The hijab wearers understood the Islamic guidelines of modest clothing as a result blending it in styling their hijab in order to keep pace with hijab trend. Hijab wearer adjusted the concept of modesty in their style in order to fit fashion into modesty is factored by media and Hijabi trendsetter. At the end of the day, the acceptance of fashionable hijab that are not compliance with Islamic modesty is conform by the society. Shaheen, Bradley \& Chi, (2015) stated that female Muslims are aware of the needs to dress up modestly and the guidelines of wearing the hijab, however they are also influenced by Western culture and the increased need to enhance their beauty by society standards. Muhammad \& Kalthom (2015) further claim that Muslim designers started blending hijab style with the latest fashion that may misled the true meaning of donning hijab. All in all, wearing a hijab is supposed to be a sign of fidelity to religiosity and recognition of the act as God's commandment but fashion designers continue to make a contemporary and stylish hijab that contrasted the modesty components which conform by the society acceptance in donning the fashionable hijab (Majid, 2016; Bohwon \& Bundhoo, 2016).

\section{Conclusion}

The blooming of fashion industry has impacted the styling of hijab. Due to this, the Islamic concept of modesty has been redefined based on the societal acceptance towards fashionable hijab. It is because the hijab wearers tend to adjust the modesty component into their fashion but when it is not suitable then they weight their appearance more on being fashionably rather than modestly. As a result, fashion has been pushed into being modest, and modest means fashion.

\section{References}

Afroza, A, R. (2017). Assertion of wearing hijab in the community: An analysis. American Scientific Research Journal for Engineering, Technology, and Sciences (ASRJETS). 29(1): 340-347.

Agorastos, A., Demiralay, C., \& Huber, C. G. (2014). Influence of religious aspects and personal beliefs on psychological behaviour: Focus on anxiety disorders. Psychology Research and Behaviour Management, 2014(7): 93-101.

Al-Qaradawi, Y. (1992). The lawful and the prohibited in Islam (al-halal wal-haram fil Islam). Translators Kamal El-Helbawy, M. Moinuddin Siddiqui, Syed Shukry. Kuwait: AlFaisal Press.

Bhowon, U., \& Bundhoo, H. (2016). Perceptive and reasons for veiling: A qualitative study. Psychology and Developing Societies. 28(1), 29-49.

Boulanouar, A.W. (2006). The notion of modesty in Muslim women's clothing: An Islamic point of view. New Zealand Journal of Asian Studies, 8(2), 134-156. 
Deniz, E. (2014, September). Veiling fashion, consumption culture and identity: A qualitative analysis for interpreting the veiled Turkish women's changing clothing practices. Paper presented at International Conference on Social Sciences and Humanities, Istanbul, Turkey.

El Guindi, F. (1999). Veil: modesty, privacy and resistance: Dress, body and culture series. Oxford and New York: Berg.

Elturk, M. (2012, July). Interview with haute hijab CEO Melanie Elturk. Haute Hijab. Retrieved from https://www.hautehijab.com/blogs/hijab-fashion/6218858-interviewwith-haute-hijab-ceo-melanie-elturk

Hasna, F., \& Hati, S. R. H. (2017, January). Hijab fashion consciousness and consumption among generations $X$ and $Y$. Paper presented at $2^{\text {nd }}$ International Conference on Financial Innovation and Economic Development (ICFIED 2017). http://dx.doi.org/10.2991/icfied-17.2017.37

Hassan, H., Anas, B. Z., \& Santosa, I. (2015). Tolerance of Islam: A study on fashion among modern and professional Malay women in Malaysia. International Journal of Social Science and Humanity, 5(5), 454-460.

Hassim, N. (2014). Hijab and the Malay Muslim woman in media. Procedia Social and Behavioural Sciences. 155(2014), 428-433.

Majid, A. A. (2016). Reading the hijab as a marker of faith in Randa Abdel-Fattah's does my head look big in this? Journal of Language Study. 16(3), 115-128.

Maqsood, E. N., Cluver, B. G., \& Chen, H. L. (2016, November). The modification of Muslim women's hijab to meet modern life styles in a Western society. Paper presented at International textile and apparel association (ITAA), Vancouver, Canada.

Muhammad, T, J. \& Kalthom, A. (2015). Fashion: Malaysian Muslim Women perspective. European Scientific Journal November Special Edition, 438-454.

Mustapha, K. (2017, October). Tudung stylists to the stars. New Straits Times. Retrieved from https://www.nst.com.my/lifestyle/flair/2017/10/295672/tudung-stylist-stars

Prihandini, P., \& Suminar, J. R. (2017). Fashionable hijab as social transformation. Annual Conference of Communication, Media and Culture (ACCOMAC), 1(1): 60-63.

Rita, A. A. (2017). Assertion of wearing hijab in the community: An analysis. American Scientific Research Journal for Engineering, Technology, and Sciences. 29(1), 340347.

Rizvi, S. M. (2014). Hijab, the Muslim women's dress, Islamic or cultural? Al-Islam.org.

Retrieved from https://www.alislam.org/hijab-muslim-womens-dress-islamic-orcultural-sayyid-muhammad-rizvi

Shaheen, M., Bradley, L. A., \& Chi, T. (2015, November). Hijab and Muslim religious identity expression among Egyptian women in the Pacific Northwest. Paper presented at International textile and apparel association (ITAA), Vancouver, Canada.

Syahrul, A. (2017, October). The meaning of religiosity for women users of slang hijab: a phenomenological study in Ugm Yogyakarta. Paper presented at 3rd International Conference on Advances in Education and Social Sciences, Istanbul, Turkey.

Woldesemait, M. (2012). The rhetoric of the modern hijab. Independent Study Project (ISP)Collection. Retrieved from: http://digitalcollections.sit.edu/isp_collection/1273

Zulkifli, A. L., \& Fatin, N. S. (2013). The roles of media in influencing women in wearing hijab: An analysis. Journal of Image and Graphics, 1(1), 50-54. http://dx.doi.org/ 10.12720/joig.1.1 